\title{
Superparamagnetic iron oxide nanoparticles combined with NGF and quercetin promote neuronal branching morphogenesis of $\mathrm{PCI} 2$ cells
}

This article was published in the following Dove Medical Press journal: International Journal of Nanomedicine

\author{
Samira Katebi ${ }^{1}$ \\ Abolghasem Esmaeili' \\ Kamran Ghaedi' \\ Ali Zarrabi ${ }^{2}$ \\ 'Cell, Molecular Biology, and \\ Biochemistry Division, Department of \\ Biology, Faculty of Sciences, University \\ of Isfahan, Isfahan, Iran; ${ }^{2}$ Department \\ of Biotechnology, Faculty of Advanced \\ Sciences and Technologies, University \\ of Isfahan, Isfahan, Iran
}

Background: The investigation of agents promoting recovery of nerve regeneration following neurodegenerative diseases has been the most important issue in neuroscience. Nerve growth factor (NGF) and quercetin as potential flavonoids could possibly have therapeutic applications in the field of degenerative diseases such as Parkinson and Alzheimer.

Materials and methods: The MTT assay was done at 24, 48, and 72 hours to examine the cytotoxicity of superparamagnetic iron oxide nanoparticles (SPIONs) and quercetin. We combined NGF and quercetin with different concentrations of SPIONs as novel compounds to study their effect on neuronal branching morphogenesis of PC12 cells.

Results: Morphological analysis showed a significant growth $(P<0.001)$ in neurite length when PC12 cells were incubated in quercetin solution. We found a significant neurite outgrowth promotion and an increase in the complexity of the neuronal branching trees after exposing PC12 cells to both quercetin and SPIONs. In addition, a higher level of $\beta 3$-tubulin expression was observed in these cells when treated with both quercetin and SPIONs.

Conclusion: Different photographic analyses indicated that iron oxide nanoparticles function as an important factor in order to improve the efficiency of NGF through improving cell viability, cell attachment, and neurite outgrowth in the shelter of quercetin as an accelerator of these phenomena. The use of the quercetin-SPION complex as a suitable method for improving NGF efficacy and activity opens a novel window for substantial neuronal repair therapeutics. Keywords: superparamagnetic iron oxide nanoparticle, quercetin, PC12 cells, NGF, differentiation, branching morphogenesis, neurodegenerative diseases, neurite, neurogenesis

\section{Introduction}

Recovery of nerve function and nerve regeneration have been the most important issues in neuroscience, due to their considerable role in the treatment of injured neurons during a degenerative disease or after an accident. ${ }^{1}$

Appropriate cell morphology regulation by intrinsic and extrinsic factors is an important requirement for cell to cell communication during the differentiation process. Neuronal cells undergo remarkable changes in cytoskeletal organization and morphology. ${ }^{2}$ Different factors have been revealed to induce neuritogenesis including different molecular signals such as extracellular matrix (ECM) proteins, growth factors, and mechanical tensile forces. ${ }^{3}$

Cell cultures of neuronal cell lines or primary neurons are usually used to study compounds controlling plasticity of neuronal processes and differentiation. In particular, PC12 cells (pheochromocytoma cell line) have been extensively used in both neurotoxicological and neurobiological studies as a model of neuronal differentiation. ${ }^{4}$
Correspondence: Abolghasem Esmaeil Cell, Molecular Biology, and Biochemistry Division, Department of Biology, Faculty of Sciences, University of Isfahan, Hezar Jarib St, Isfahan 8I746-7344I, Iran

Tel +983137932490

Fax +98 3I3 7932456

Email aesmaeili@sci.ui.ac.ir

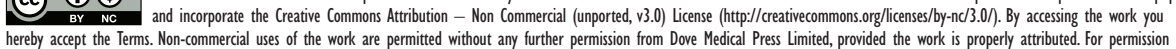
for commercial use of this work, please see paragraphs 4.2 and 5 of our Terms (hitps:s/ wwww.doveppess. com/terms.php). 
The nerve growth factor (NGF) as an important growth factor is critical for the neuritogenesis and maintenance of neurons under in vitro and in vivo conditions. NGF-incubated PC12 cells stop proliferation, outspread neurites, and become electrically impulsive. During differentiation with NGF, the tyrosine kinase receptor $\mathrm{A}$ is activated and initiates a number of signaling pathways containing phosphatidylinositol 3-kinase pathway, and the extracellular signal-regulated kinase (ERK) cascade, which obstructs proliferation and encourages neurite growth. ${ }^{4,5}$

For improving the natural effect of growth factors, nanotechnology has been proposed as a considerable item in therapeutic and diagnostic fields. Especially, magnetic nanoparticles (MNPs) could have different therapeutic applications such as cell-labeling, drug delivery, and medical imaging. ${ }^{6,7}$

The superparamagnetic iron oxide nanoparticles (SPIONs) with characteristics such as nano size, modified surfaces, monodispersed shape, enhanced magnetization, colloidal stability, bio-distribution, and cellular uptake are considerably focused for their applications in biomedical applications. ${ }^{6-8}$ Furthermore, the surface of SPIONs could be modified by different organic materials, such as polymers and biomolecules.

Biological molecules in different cells may also be bound to the surface of iron oxide nanoparticles. The interactions between biological molecules and iron oxide nanoparticles are studied to determine the cellular response of the MNPs. ${ }^{7,9,10}$

It has been shown that metal ions including cobalt, manganese, and iron could modify cell attachment and have an important impact on neuronal differentiation., ${ }^{911,12}$ These ions are related to adhesion molecules (exactly the RGD-dependent ECM). Cell adhesion molecules modulate cell proliferation, differentiation, survival, and migration by interacting with the ECM. ${ }^{13,14}$

So far, the potential cytotoxicity of MNPs due to the formation of reactive oxygen species (ROS) remains an issue of debate. ${ }^{15}$ Great efforts have been taken to eliminate the cytotoxic effects of nanoparticles such as coating or combination of iron oxide nanoparticle with different agents. ${ }^{16-18}$

Recent research has indicated that a variety of natural flavonoids reduce the toxicity of ROS in neural cells by their antioxidant activity. ${ }^{19-21}$ It is important to note that a selected group of flavonoids (such as quercetin and fisetin) have demonstrated neuroprotective activity and play a critical role in the neurite outgrowth and differentiation of neural cells..$^{20,22}$

An important natural bioflavonoid is quercetin $\left(3,3^{\prime}, 4^{\prime}, 5^{\prime}-7\right.$-penta-hydroxy flavone, Figure 1$)$. This flavonoid

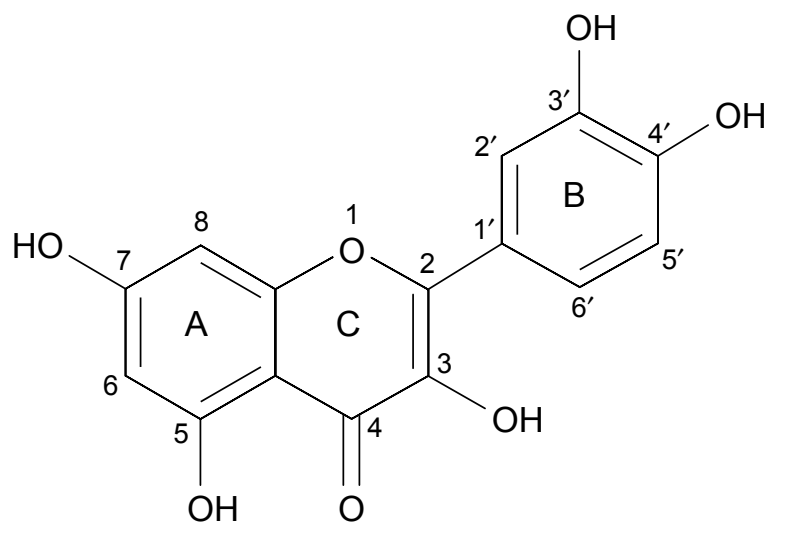

Figure I The two dimensional chemical structure of quercetin.

is abundantly found in vegetables, edible fruits, and medicinal plants. It has an extensive range of chemotherapeutic applications for many diseases such as anti-viral, anti-cancer, and anti-oxidant. ${ }^{23-25}$ A number of quercetin actions make it an important neuroprotective agent, including interaction with different proteins and protective effects of neuronal cells from oxidative stress. ${ }^{26}$

In this study, we suggest a new combination of SPIONs and quercetin to enhance the effect of NGF during neural differentiation of cells. In this combination, the role of iron oxide nanoparticles is more prominent. By increasing the attachment of PC12 cells, iron oxide nanoparticles help to preserve viability of cells and increase the effect of NGF and quercetin. Quercetin could bind to NGF and enhance the effect of NGF. ${ }^{9,27}$ We used PC12 cells as a model for studying different aspects of developmental cell biology. Based on morphometric assessments, we show that the combination of SPIONs and quercetin promotes neuronal branching morphogenesis of PC12 cells in the presence of NGF.

\section{Materials and methods Materials}

Poly-L-ornithine (PLO), MTT, quercetin (3,3', $4^{\prime}, 5^{\prime}$-7-pentahydroxy flavone), and PBS were obtained from Sigma-Aldrich Co. (St Louis, MO, USA). Horse serum (HS), T-25, T-75 flasks, 12-well and 96-well plates, and L-glutamine were purchased from Corning Incorporated (Corning, NY, USA). BSA, FBS, penicillin-streptomycin, and RPMI medium were bought from Thermo Fisher Scientific (Waltham, MA, USA). NGF- $\beta$ (GFM11) obtained from Cell Guidance Systems (St Louis, MO, USA). Iron oxide nanoparticles (Nano-screen MAG-DXS) were purchased from Chemicell $\mathrm{GmbH}$ (Berlin, Germany). PC12 cell line (National Center for Biotechnology code: C153) was purchased from Pasteur Institute of Iran (Tehran, Iran). 


\section{Cell culture}

PC12 cells were cultured in the RPMI medium containing $10 \% \mathrm{HS}, 5 \% \mathrm{FBS}, 1 \%$ L-glutamine, and antibiotics. For differentiation, $\mathrm{PC} 12$ cells $\left(5,000\right.$ cells $\left./ \mathrm{cm}^{2}\right)$ were seeded on PLO/laminin (Sigma-Aldrich Co.)-coated plates and incubated for 24 hours in serum-reduced media $(0.5 \%$ FBS, $1 \%$ HS). Recombinant mouse NGF- $\beta$ ( $50 \mathrm{ng} / \mathrm{mL}$ ) was then added to the medium (every 2 days) to induce the differentiation of $\mathrm{PC} 12$ cells. Five treatments were examined: $50 \mathrm{ng} / \mathrm{mL}$ (free NGF), $100 \mathrm{ng} / \mathrm{mL}-\mathrm{NGF}$, MNPs, NGFquercetin $(10 \mu \mathrm{M})$, and NGF + MNPs + quercetin.

\section{Cell viability assay}

To examine the cytotoxic effects of quercetin and MNPs on PC12 cells, MTT assay was applied. The cells (30,000/well) were seeded onto the PLO-coated 96-well plates. At 24, 48, and 72 hours after incubation with the MNPs and quercetin at concentrations ranging from 10 to $100 \mu \mathrm{g} / \mathrm{mL}$ for MNPs and $10-50 \mu \mathrm{g} / \mathrm{mL}$ for quercetin, PC12 cells were incubated with $0.5 \mathrm{mg} / \mathrm{mL}$ MTT according to the Mosmann method. ${ }^{28}$ The absorbance at $560 \mathrm{~nm}$ was measured using the ELISA reader (Thermo LabSystems Inc., Beverley, MA, USA).

\section{Quantification of nanoparticle intracellular uptake}

In order to quantitate the intracellular uptake of nanoparticles by the PC12 cells, following experiments have been performed.

\section{Inductive coupled plasma-atomic emission spectrometer (ICP-AES)}

Total MNPs in the cell cytoplasm were measured by evaluating the amount of iron in PC12 cells. PC12 cells were incubated with different concentrations of iron oxide nanoparticles (from 10 to $100 \mu \mathrm{g} / \mathrm{mL}$ ). After 24 hours of incubation, the cells were sequestered and lysed with hydrochloric acid. Iron absorption was quantified using an ICP-AES (ICPS-7500; Shimadzu Corp., Kyoto, Japan). ${ }^{29}$

\section{Flow cytometric analysis}

In this study, dextran sulfate-coated MNPs sized $100 \mathrm{~nm}$ were used (Nano-screen MAG-DXS). The surface coating of nanoparticles was dextran sulfate with a fluorophore that has an absorbance maximum of $476 \mathrm{~nm}$ and an emission maximum of $490 \mathrm{~nm}$. All samples (incubated cells with iron oxide nanoparticles at concentrations ranging from 10 to $100 \mathrm{mg} / \mathrm{mL}$ ) were analyzed by flow cytometry (FACSCalibur; BD Biosciences, San Jose, CA, USA). Green fluorescence was detected using an FL-1 sensor, a $525 \mathrm{~nm}$ band-pass filter. Statistics from 10,000 cells per sample were analyzed and three measurements per sample were recorded.

\section{Prussian blue staining}

PC12 cells treated with different concentrations of iron oxide nanoparticles were stained with Prussian blue dye for tracing iron in the cell cytoplasm by dipping the cells in a mixture of equal parts of $10 \%$ potassium ferrocyanide solution and $20 \%$ hydrochloric acid. In this method, trivalent iron in the PC12 cells interacts with the ferrocyanide and results in the formation of ferric ferrocyanide (the blue pigments).$^{30} \mathrm{~A}$ light microscope (Inverted Microscope; Nikon, Tokyo, Japan) was used to acquire images of stained cells.

\section{Cresyl violet staining (Nissl staining)}

The cresyl violet method was used to show the Nissl substance as an important characteristic of neurons. In the neural differentiation, the maturation grade of neuronal cells is reflected by formational changes in the neuroplasm. The Nissl bodies are rough endoplasmic reticulum (with ribosomes) and are the site of protein synthesis. ${ }^{31} \mathrm{PC} 12$ cells were stained with $0.1 \%$ cresyl violet solution for $4-15$ minutes and washed three times with PBS to remove excess stain. PC12 cells were photographed by inverted microscopy and scored for the presence of Nissl substance and neurites.

\section{Immunocytochemistry}

PC12 cells were immunostained against $\beta 3$-tubulin (in green) as an important neural specific marker. To stain PC12 cells with antibodies against $\beta 3$-tubulin, cultures were fixed with $4 \%$ for 30 minutes and permeabilized with $0.3 \%$ Triton X-100 diluted in PBS. PC12 cells were incubated with the primary antibody ( $\beta 3$-tubulin) for 24 hours and then treated with a fluorescein isothiocyanate-conjugated secondary antibody for 1 hour. The nuclei were marked with DAPI for 15 minutes. Light and fluorescent microscopy (Olympus US SZX12 fluorescent stereo microscope; Olympus Corporation, Tokyo, Japan) identified the temporal relationship between neurites morphogenesis and different treatments.

\section{Neuritogenesis in $\mathrm{PCI} 2$ cells}

Neuritogenesis in PC12 cells was studied in a time-dependent method with different treatments either alone or in combination for 5 days. NGF- $\beta(50 \mathrm{ng} / \mu \mathrm{L})$ was added to the medium of all treatments because this concentration was optimized. Due to lack of serum in the differentiation medium, NGF should be added to the cell culture every 2 days to maintain the viability of the PC12 cells during 
differentiation process. NGF blocked the apoptotic death of attached cells. ${ }^{9}$

PC12 cells were incubated with NGF and MNPs with or without quercetin. At different days (from 1 to 5) after incubation, the percentage of neurite outgrowth, number of branching points, and number of neurites originating from soma were quantified (three random images from triplicate tests). Neuritogenesis was measured as described by Kim et al. ${ }^{29}$ Neurite length was defined as L0 to L4 according to the length of the neurites. L0 was demarcated as cells with no neurites, L1 as cells whose neurite length was shorter than the size of the soma, L2 as cells with neurite length between the original size of the soma and twice the size, and L3 as cells whose neurite length was longer than twice the size of soma. ${ }^{29}$ Also the number of neurites originating from soma were defined as N1, N2, N3, and N4 (N1, N2, N3, and N4 were defined as one, two, three, and four neurites in the PC12 cells, respectively). Length and number of neurites of 200 cells were measured in three random fields from triplicate experiments.

\section{The effect of different treatments on neuritogenesis}

First, the efficiency of free NGF as a differentiating factor was measured. Then, the efficiency of free NGF treatment was compared to other treatments such as quercetin solution and using iron oxide nanoparticles with or without quercetin. The PC12 $\left(2 \times 10^{3}\right)$ cells were plated on PLO-coated plates and incubated with five different treatments including free $\mathrm{NGF}, \mathrm{NGF}(50 \mathrm{ng} / \mathrm{mL})$ and quercetin $(10 \mu \mathrm{M})$, quercetin-NGF-MNPs $(20 \mu \mathrm{g} / \mathrm{mL})$, and NGF-MNPs $(20 \mu \mathrm{g} / \mathrm{mL})$. After incubation in different treatments, PC12 cells were washed and fixed with $4 \%$ paraformaldehyde for 30 minutes. Percentage of neurite outgrowth, branching points, and differentiation of PC12 cells under different treatments were measured using the light microscope. Light and fluorescent microscopy was used to evaluate both the terminal branch number and the total branch length of neurites.

\section{Statistical analysis}

All values of differentiation rate of PC12 cells are presented as mean $\pm \mathrm{SD}$. The analysis method was a one-way ANOVA. When the $P$-value was $<0.05(P<0.05)$, differences among the treatments were considered statistically significant.

\section{Results}

In this study, uniform fluorescent iron oxide $\left(\mathrm{Fe}_{3} \mathrm{O}_{4}\right)$ nanoparticles were used. The surface of the nanoparticles was coated with dextran sulfate with a green fluorophore. The number of particles was $\sim 1.8 \times 10^{15} / \mathrm{g}$ with a density of $1.25 \mathrm{~g} / \mathrm{cm}^{3}$. The size distribution of the dextran sulfate-coated iron oxide nanoparticles was found to be $100 \mathrm{~nm}$ (Figure 2A). Figure 2B shows the energy dispersive $\mathrm{X}$-ray pattern of dextran-coated iron oxide nanoparticles $\left(\mathrm{Fe}_{3} \mathrm{O}_{4}\right)$, and their sizes were determined by scanning electron microscopy.

The MTT cell viability assay was employed to examine the cytotoxicity of SPIONs and quercetin. PC12 cells were treated with SPIONs at different concentrations from 10 to $100 \mu \mathrm{g} / \mathrm{mL}$. Figure 3 shows the effects of different treatments on the viability of PC12 cells. Superparamagnetic nanoparticles in the concentration of $100 \mu \mathrm{g} / \mathrm{mL}$ show significant cytotoxicity in comparison with the control and other groups $(P<0.01)$. Quercetin in the range of $60-100 \mu \mathrm{g} / \mathrm{mL}$ was significantly cytotoxic (Figure 3D).

Total MNPs in the cell cytoplasm were measured by evaluating the amount of iron in the PC12 cells using ICPAES (Figure 4A). During incubation with different concentrations of MNPs, iron in the cell cytoplasm increased up to the 35 pg per cell.
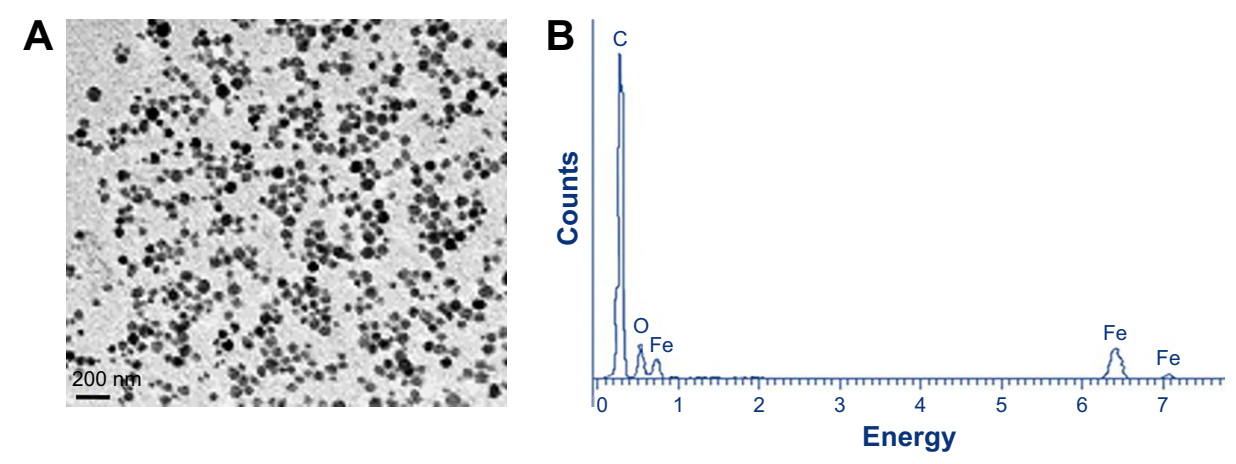

Figure 2 SEM (A) and EDX (B) images of iron oxide nanoparticles used for neurite outgrowth.

Abbreviations: C, carbon; Fe, iron; O, oxygen; SEM, scanning electron microscope; EDX, energy dispersive X-ray analysis. 

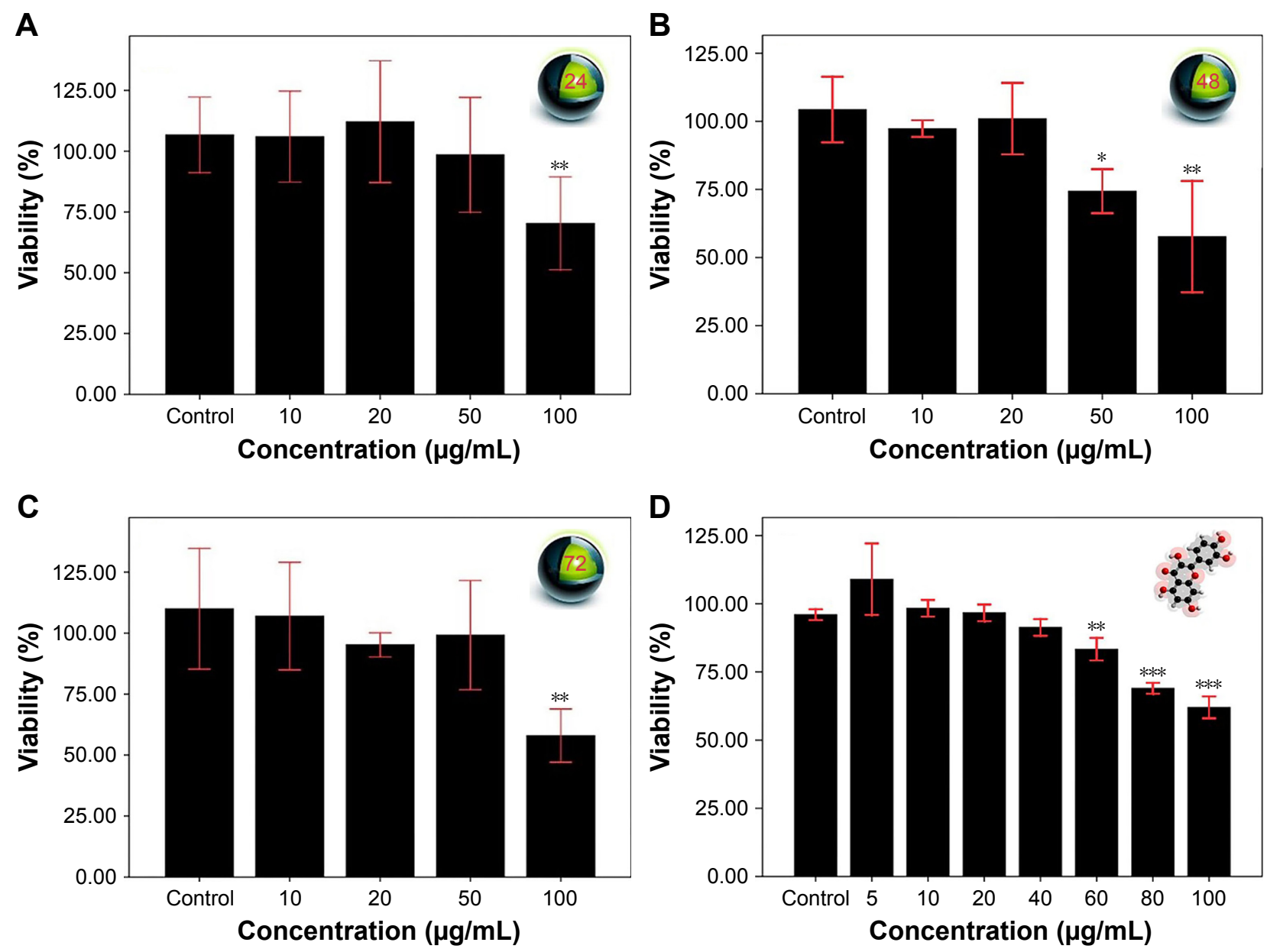

Figure 3 Effect of different treatments on the viability of PCI2 cells. Cell viability was determined by MTT assay. PCI 2 cells were treated with I0, 20,50 , and I00 $\mu$ g/mL for 24 (A), 48 (B), and 72 hours (C). (D) PCI2 cells were treated with 5, 10, 20, 40, 60, 80, and $100 \mu \mathrm{g} / \mathrm{mL}$ for 24 hours. There were significant differences between the viability of $\mathrm{PCl} 2$ cells from different treatments $(P<0.05)$. Data are presented as the mean $\pm S D, n=3, * P<0.05, * * P<0.0$ I, and $* * * P<0.00$ I vs control group.

The fluorescent microscopic study of the PC12 cells treated with different concentration of iron oxide nanoparticles exhibited a bright green color emission as shown in Figure 4B. These data show that the majority of superparamagnetic nanoparticles were internalized into the cells.

Also as it is shown in Figure 4C, treatment of PC12 cells with different concentration of iron oxide nanoparticles (10 $50 \mu \mathrm{g} / \mathrm{mL}$ ) led to an increase in fluorescence up to $89 \% \pm 0.7 \%$ intensity (yellow, violet, and blue curves). Surprisingly, during the use of maximum concentration of MNPs, the fluorescence intensity of about $97 \%$ was recorded (red curve).

PC12 cells incubated with iron oxide nanoparticles were also stained for tracing the iron in the PC12 cell cytoplasm (Figure 4D). The red arrow represents the position of the MNPs in PC12 cells (dark blue dots).

Based on the internalization and MTT assay results and considering published articles, a dose of $20 \mu \mathrm{g} / \mathrm{mL}$ for nanoparticle and a dose of $10 \mu \mathrm{M}$ for quercetin were chosen. Differentiation was studied by observing the morphology of PC12 cells. First, the efficacy of free NGF as a differentiating factor was experienced. As shown in Figure 5, when PC12 cells were treated with free NGF, neurite outgrowth and neurite arborization were observed. While the use of NGF with quercetin led to an increase in neurite outgrowth between 1 and 5 days after differentiation induction (exactly neurite length). As shown in Figure 6A, the Nissl substance was represented dark blue due to the staining of ribosomal RNA. The distribution of the neurite length of PC12 cells 5 days after the induction of differentiation is shown in Figure 6B. Neurite length was significantly affected by the quercetin treatment. The percentage of the PC12 cells with longer neurite (L3 and L4) increased when quercetin was added to the cells (Figure 6C). To examine the effect of MNPs on 
A

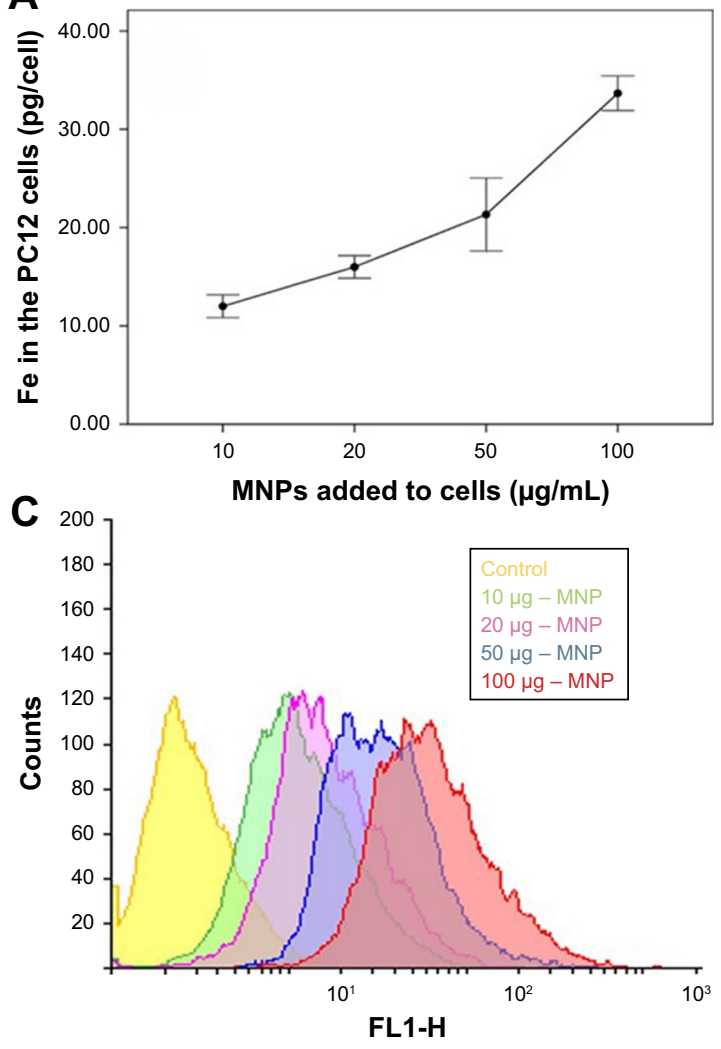

D

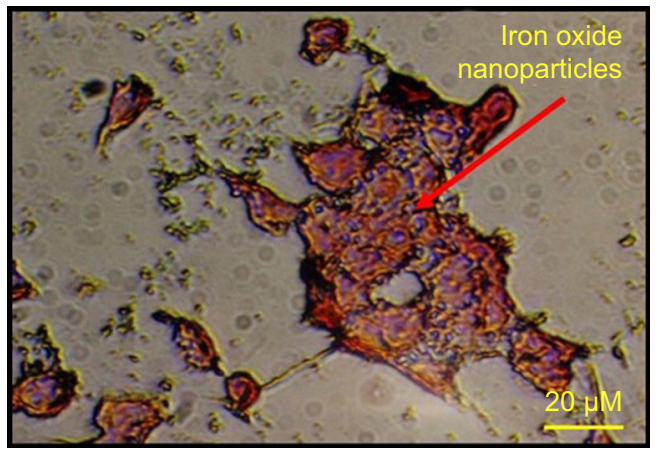

B
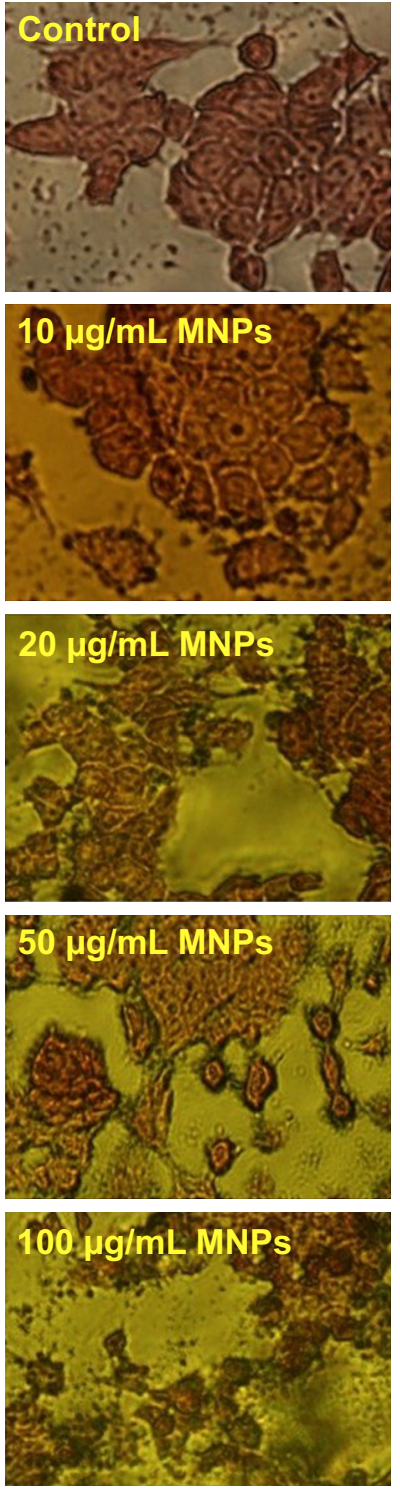
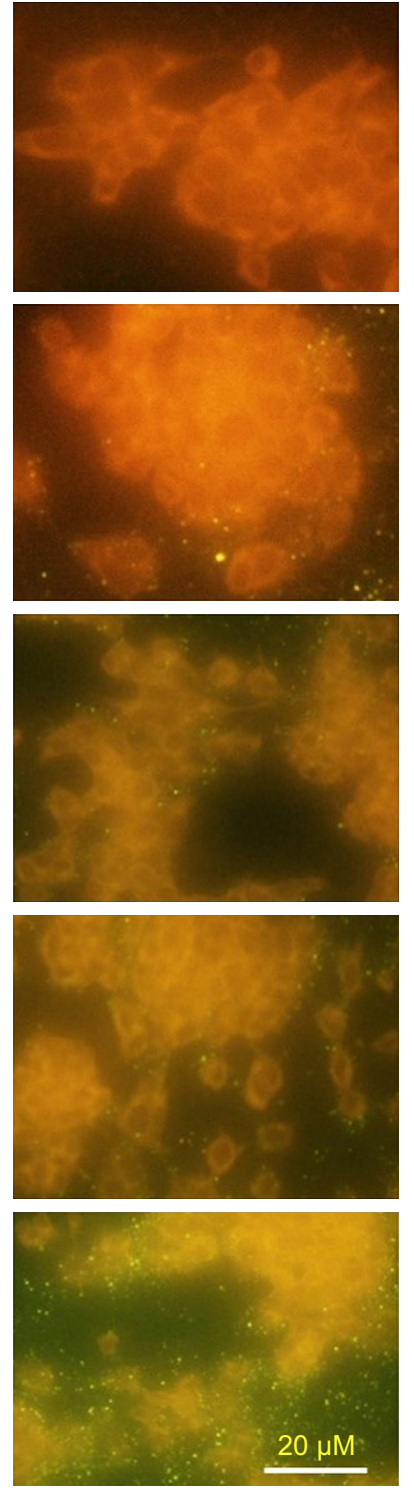

Figure 4 Internalization of superparamagnetic iron oxide nanoparticles into the PCI 2 cells. (A) Uptake of iron oxide nanoparticles by PCI 2 cells 24 hours after exposure to the iron oxide nanoparticles. Iron oxide nanoparticles were added to the media in a dose-dependent manner ranging from 10 to $100 \mu g / \mathrm{mL}$. (B) Fluorescent images of incubated cells with the different concentrations of fluorescent iron oxide nanoparticles. (C) Different histograms using Flowing Software (version 2.5.I) were combined: the red curve represents the maximum fluorescence. In this case, PCI2 cells were incubated with $100 \mu \mathrm{g} / \mathrm{mL}$ of iron oxide nanoparticles. (D) Prussian blue method: PCI 2 cells treated with iron oxide nanoparticles were also stained for tracing the iron in the cell cytoplasm. Arrow represents the position of the iron oxide nanoparticles in PCI 2 cells (dark blue dots).

Abbreviation: MNPs, magnetic nanoparticles.

neuronal differentiation, PC12 cells were incubated with a combination of NGF and iron oxide nanoparticles. The results showed that the number of neurites originating from the soma and branching points of the cells increased when PC12 cells were incubated with iron oxide nanoparticles (Figure 7B).

PC12 cells incubated with NGF and MNPs developed more branching points, more neurites per cell, and maximum percentage of cells expressing neurites in comparison with other groups (Figure 7D). Surprisingly, the treatment of PC12 cells with iron oxide nanoparticles together with NGF and quercetin demonstrated considerable enhancement in the neurite lengths and branching points in comparison with those treated with free NGF (Figures 7 and 8). Neural-specific marker ( $\beta 3$-tubulin) was studied immunohistochemically using specific monoclonal antibodies in PC12 cells incubated with NGF and SPIONs (Figure 9).

Several studies have shown that 1 day after incubation of PC12 cells on the PLO-coated plate, neuritogenesis and neurite arborization have begun as an important 


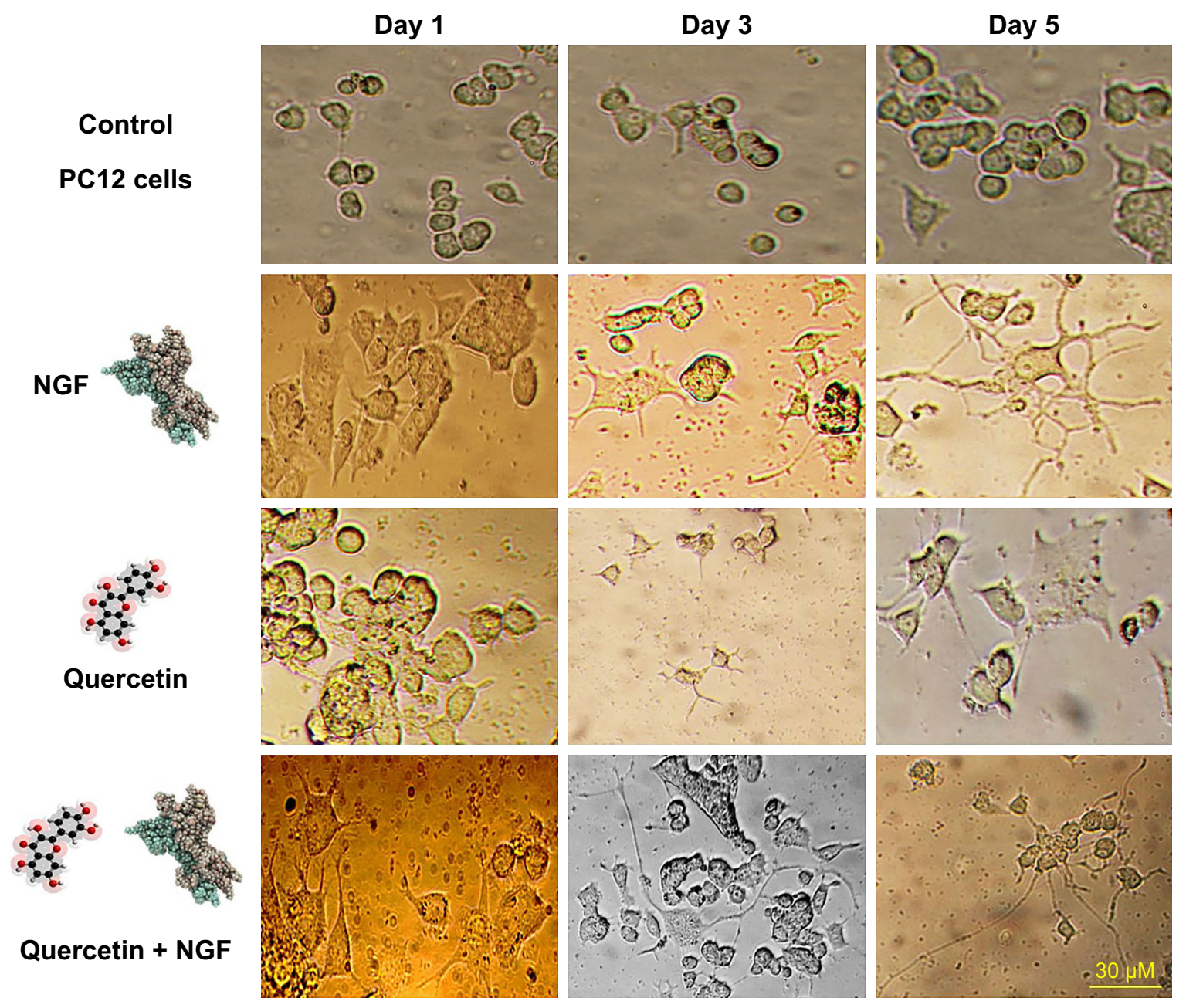

Figure 5 Typical images of differentiated PCI 2 cells at I, 3, and 5 days after treatment with NGF (50 ng/mL) and quercetin (I0 $\mu$ M) and NGF + quercetin. Quercetin induces $\mathrm{PCl} 2$ cell differentiation (magnification: 200x).

Abbreviation: NGF, nerve growth factor.

neuronal differentiation stage (Figure 5). Figure 7 shows neuritogenesis in PC12 cells cultured for 3 days in NGF + MNP treatment. Neurite outgrowth in PC12 cells treated with NGF + quercetin was considerable, although the neuronal processes have fewer branches than comparable processes in MNP treatment (Figure 7). Measurement of branching points, neurites per cell, and percentage of cells expressing neurites in cells cultured in different treatments show that PC12 cells grown in MNP treatment have significantly more branches than those treated with NGF or quercetin (Figures 7 and 8). The branching frequency on the $\mathrm{NGF}+\mathrm{MNPs}+$ quercetin was significantly higher than the branching frequency of neurons in NGF + MNP treatment (Figures 7 and 8).

\section{Ethics statement}

No animal or human subjects were used in this study.

\section{Discussion}

PC12 cells are an important model system by which to study how growth factors and external signals initiate neuronal differentiation. In this study, we have described an important nano-based combination of iron oxide nanoparticles and quercetin to enhance the effect of NGF during neural differentiation of cells. The data from the MTT assay demonstrated that quercetin and dextran sulfate-coated SPIONs possess low cytotoxicity at low concentration. Increasing the concentration of iron oxide nanoparticles leads to cellular dysfunction and the development of neurological diseases. ${ }^{17,32}$ Pisanic et al reported that $\mathrm{Fe}$ at $1.5 \mathrm{mM}$ concentration is very toxic to PC12 cells. ${ }^{33}$ Based on the data presented in this study, when the concentration of iron oxide nanoparticles was $<50 \mu \mathrm{g} / \mathrm{mL}$, there was no significant difference in the viability of PC12 cells. Under our experimental conditions, iron oxide nanoparticle treatment increased the efficacy of 


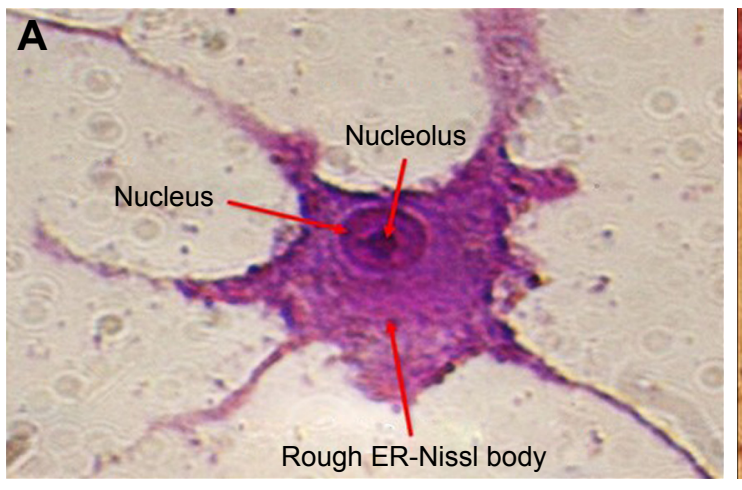

C

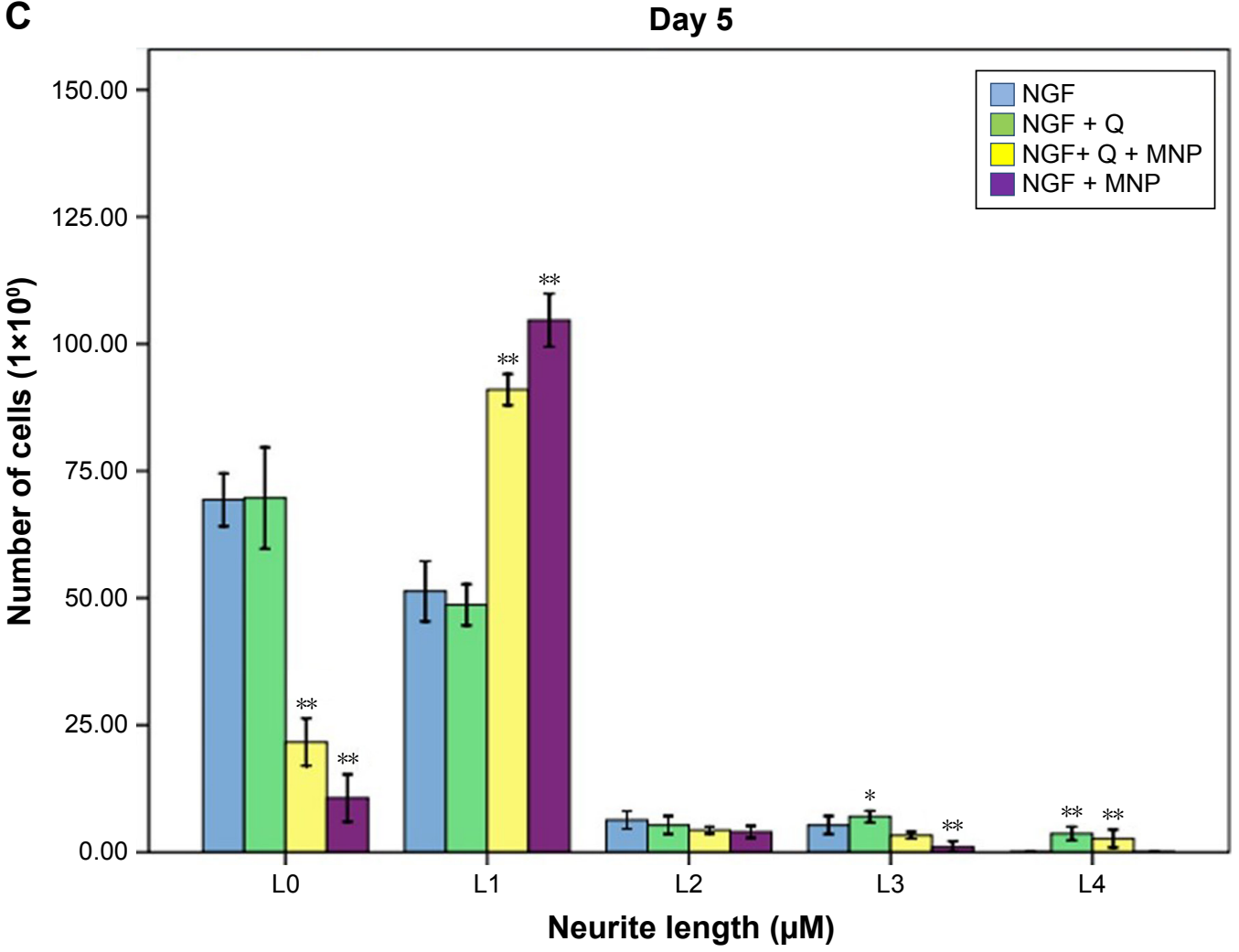

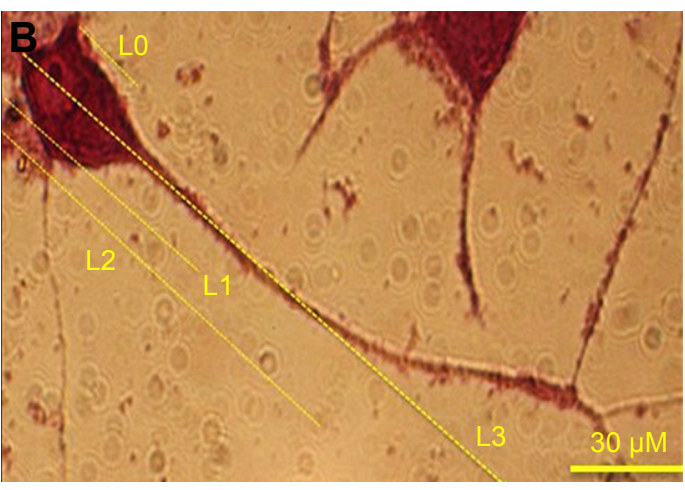

Day 5

Figure 6 Neurite outgrowth of PCI2 cells. (A) Cresyl violet staining: the Nissl substance (rough endoplasmic reticulum) appeared dark blue due to the staining of ribosomal RNA. Magnification $\times 400$. (B) Distribution of the neurite length of PCI 2 cells 5 days after the induction of differentiation (LO refers to the cells without neurites; LI refers to the cells with neurites whose length is shorter than the size of the cell body; L2 refers to the cells with neurites whose length is between the original and twice the size of the cell body; L3 refers to the cells with neurites whose length is longer than twice the size of the cell body). (C) Neurite length of PCI 2 cells under different treatments. Cells were scored positive if one or more neurites with length $>$ I cell body diameter was observed. The results presented are the mean $\pm S D$ of 10 independent experiments. $* P<0.05$, $* * P<0.01$. Abbreviations: NGF, nerve growth factor; Q, quercetin; MNP, magnetic nanoparticle.

NGF compared to those that were incubated with free NGF. Flow cytometry technique, Prussian blue staining, and ICPAES allowed us to observe and quantify the intracellular MNP content in PC12 cells.

A considerable issue in this study is the significant increase of neurite length and branching point when MNPs and quercetin were applied together. Kim et al demonstrated that MNPs taken up by PC12 cells improved neurite outgrowth, especially the percent of neurite-bearing cells. ${ }^{29}$ This behavior is observed in a dose-dependent manner. 

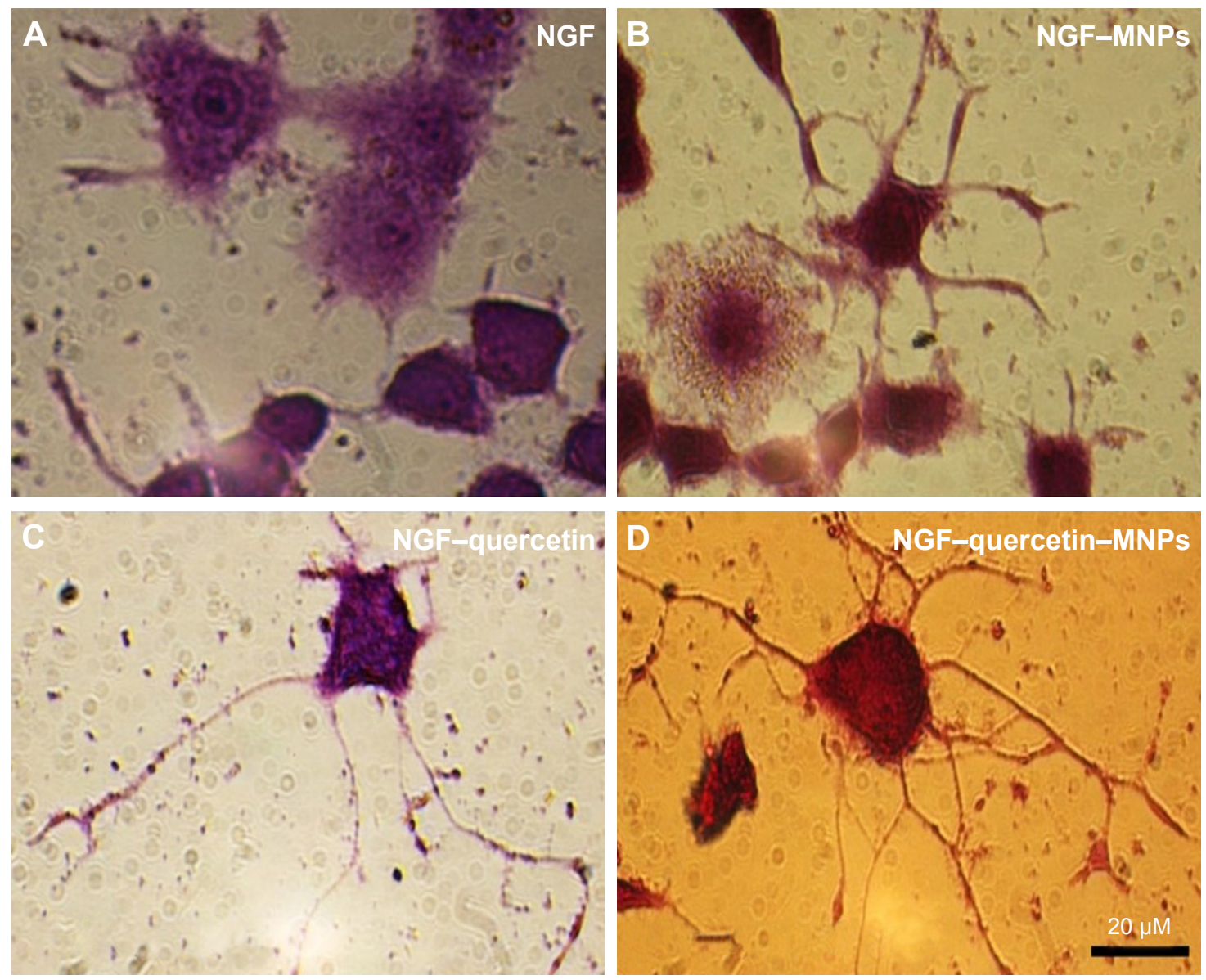

Figure 7 Compartment between different treatment effects on neurite morphology. PCI 2 cells were treated with NGF $(\mathbf{A}), \mathrm{NGF}+\mathrm{MNPs}(\mathbf{B}), \mathrm{NGF}+$ quercetin $(\mathbf{C})$, and NGF + quercetin + MNPs (D). For each treatment, 100 cells in each of three separate fields were counted.

Abbreviations: MNPs, magnetic nanoparticles; NGF, nerve growth factor.

related to cell morphology and behavior including receptors of growth factors, ion channels, and the cytoskeleton. ${ }^{5,29,36}$

Berry et al demonstrated extensive changes in gene expression of human fibroblasts when treated with MNPs. ${ }^{37}$
These genes were associated with the receptors of growth factors, ion channels, collagen, laminin, cytoskeleton, and different proteins related to cell movement and cell interactions (Figure 10). ${ }^{38} \mathrm{Kim}$ et $\mathrm{al}^{29}$ proposed a hypothesis to

A

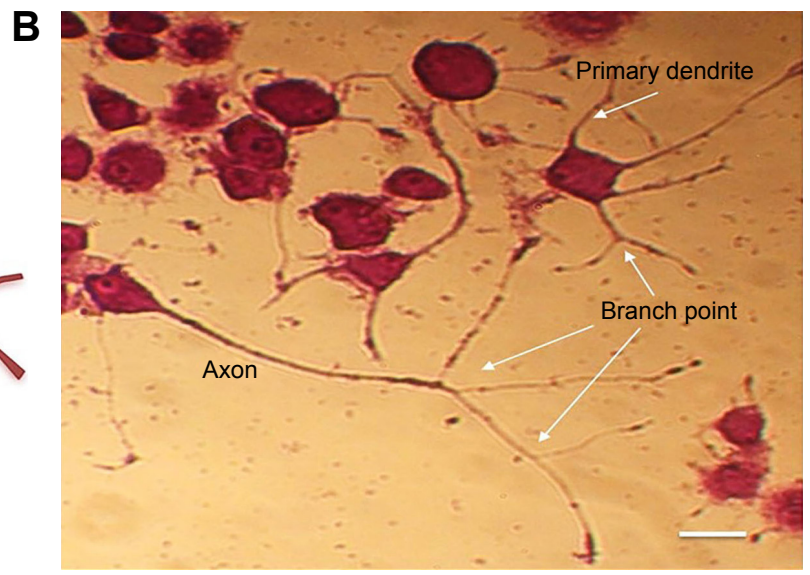

Figure 8 (Continued) 

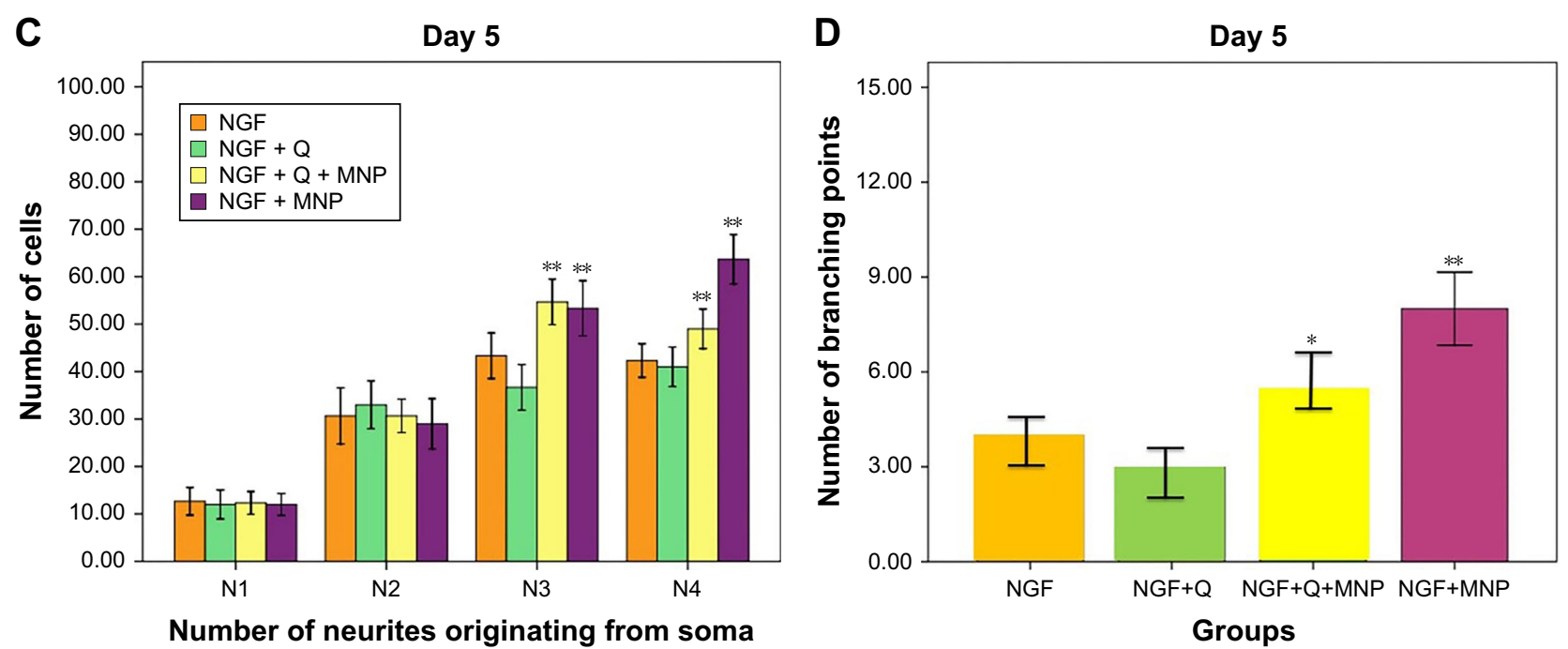

Figure 8 Effect of different treatments (NGF-MNPs-quercetin) on morphological parameters of neuronal differentiation, comparing between the four treatments: free NGF, non-conjugated MNPs with free NGF, NGF-MNPs + quercetin, and NGF + quercetin (A, B). (C) The number of neurites originating from the soma. Scale bar set at $30 \mu$ M. (D) The number of branching points. ANOVA test, $* P<0.05$, $* * P<0.01$.

Abbreviations: MNPs, magnetic nanoparticles; NGF, nerve growth factor; Q, quercetin.
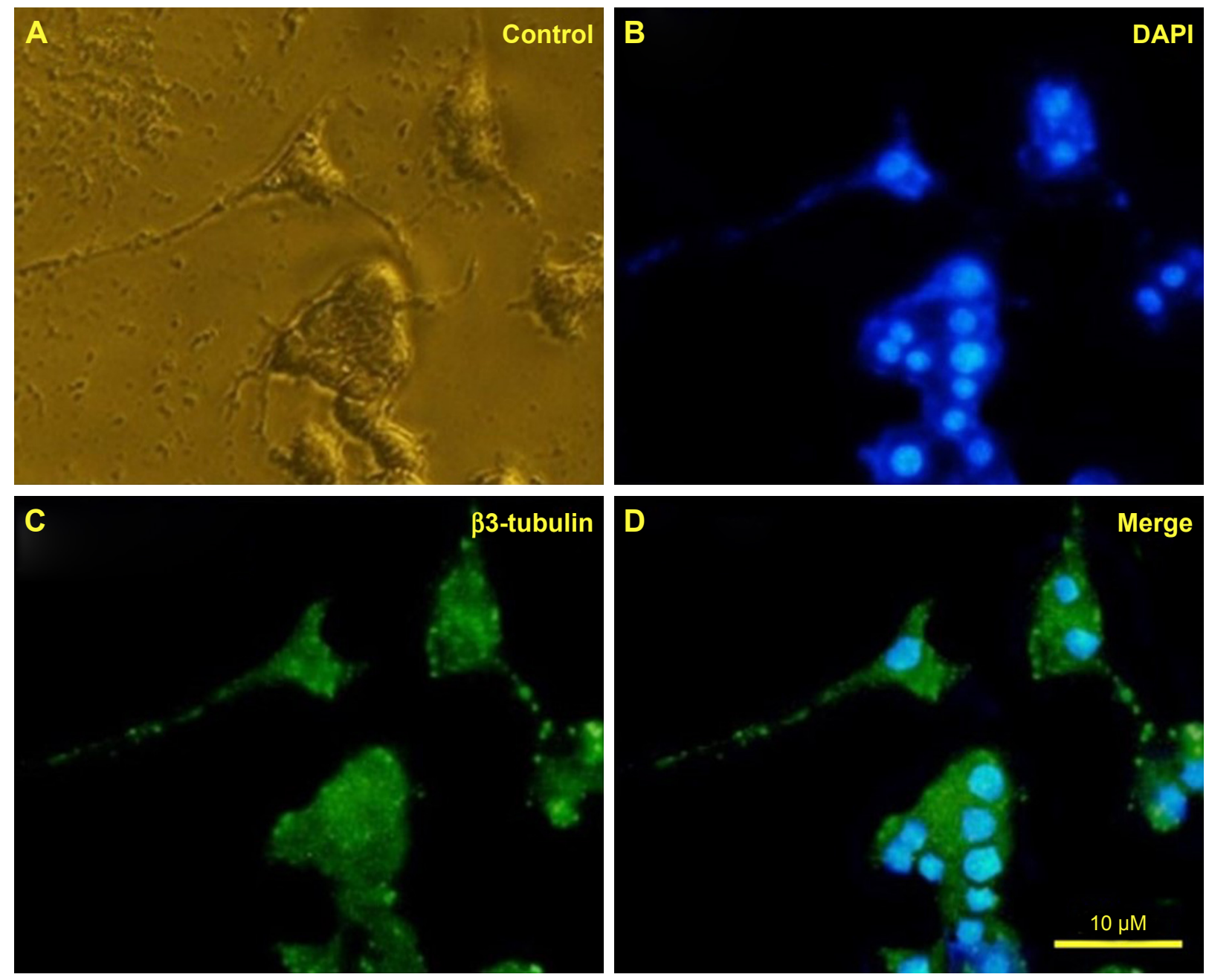

Figure 9 Immunofluorescence images of differentiated PCI2 cells 5 days after treatment with iron oxide nanoparticles. (A) Control, (B) cells stained with DAPI, (C) cells stained with $\beta 3$-tubulin, and (D) the merge of (B) and (C). Green and blue fluorescence represent $\beta 3$-tubulin and nucleus, respectively. Nuclei marked with DAPI. 


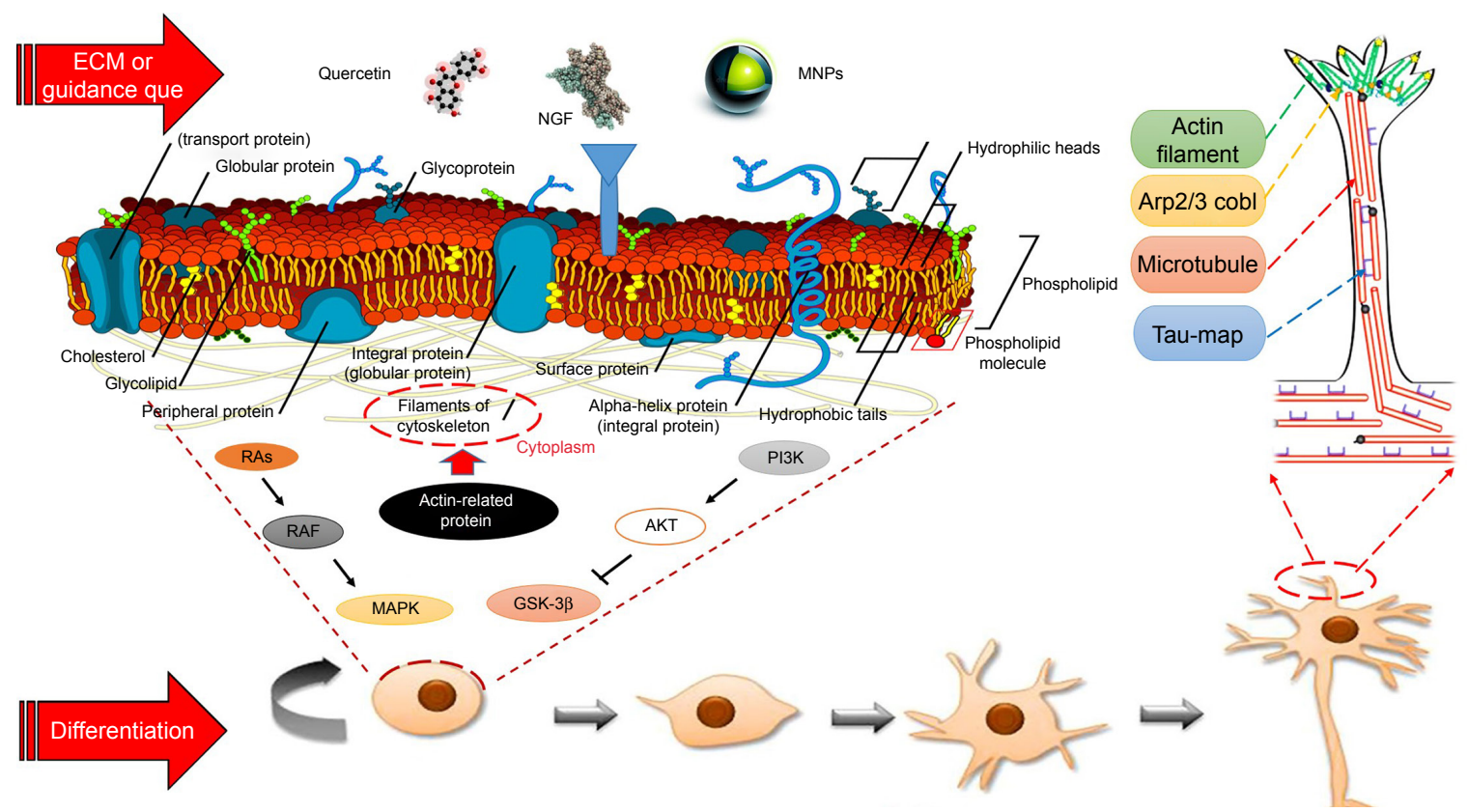

Figure 10 Schematic representation of different treatments (NGF plus iron oxide nanoparticle and quercetin) effects on PCI 2 cell signaling during differentiation. Growth factors such as NGF are optimally activated by their ligands but only under the appropriate condition of cell attachment. MNPs and quercetin as the neuroprotective agents induced neurite outgrowth by an ERK-dependent process.

Abbreviations: ERK, extracellular signal-regulated kinase; NGF, nerve growth factor; MNP, magnetic nanoparticle; ECM, extracellular matrix.

presume the state of $\mathrm{Fe}$ ions. In this hypothesis, $\mathrm{Fe}$ ions were released from internalized MNPs due to acidic $\mathrm{pH}$ inside the internal organelles and promoted neuritogenesis.

How can quercetin affect differentiation? The data presented in our study demonstrated that neurite length was significantly affected by the quercetin treatment. This flavonoid is capable of inducing PC12 cell differentiation and can surprisingly enhance the efficacy of NGF function. ${ }^{27}$

Tangsaengvit et al demonstrated that quercetin at a very low concentration of $1 \mathrm{~nm}$ improved the viability of P19derived neurons, considerably increased neuritogenesis. ${ }^{39}$ Ishige et al demonstrated that certain flavonoids can protect different cell lines from oxidative stress. Some of these flavonoids (such as quercetin and fisetin) are also capable of inducing PC12 cell differentiation. ${ }^{19}$

The bioflavonoids fisetin and quercetin were reported to have a stimulatory effect on alkaline phosphatase activity through the ERK signaling pathway. ${ }^{40,41}$ Quercetin has an additional hydroxyl group at C-5 than fisetin. Therefore, based on quercetin antioxidant properties, this bioflavonoid has the ability to improve differentiation through modulation of signal cascades. ${ }^{19,26}$

Sagara et al reported that four-oxo group and 2,3-double bond in the $\mathrm{C}$ ring of quercetin play a significant role in quercetin neuroprotective effects. ${ }^{42,43}$ They indicated that Ras-ERK cascade is essential for quercetin-induced
PC12 cell differentiation. Also, the results of Sagara et al showed that three different mitogen/extracellular signalrelated kinase inhibitors block both flavonoid-induced ERK activation and differentiation of $\mathrm{PC} 12$ cells. ${ }^{26}$

In this study, we examined neurite branching morphogenesis in PC12 cells under different treatments. We present in vitro results that demonstrate neuritogenesis and neurite arborization in the presence of extracellular factors. We established that iron oxide nanoparticles can enhance neurite branching and produce more complex branching trees and that quercetin can increase the length of neurites. Combination of MNPs with quercetin leads to considerable enhancement in the neurite lengths and branching points.

How do neurite branches form during the development of PC12 cells? Actin rearrangements are extremely controlled by actin-associated proteins, which have essential roles in neuritogenesis and neurite arborization (Figure 10). A highly dynamic area is found at the tips of growing neurites, where extreme rearrangements of actin filaments and microtubules occur during neurite elongation. ${ }^{44}$ Recent studies have shown the importance of enabled/vasodilator-stimulated phosphoprotein proteins, formins, actin-related protein $2 / 3$, and cordon-bleu in the neurite morphogenesis. ${ }^{45,46}$

In the present study, we have described a new effective combination of quercetin and iron oxide nanoparticles with neuroprotective effects that are capable of promoting 
neuritogenesis at a high level. This combination has great potential for increasing neuronal differentiation and may function as a novel therapeutics in the field of neuronal regeneration and repair.

\section{Conclusion}

While it is well recognized that different cells can respond to various external signals during neuritogenesis and neurite arborization, only limited studies have examined the effects of SPIONs and quercetin on neural differentiation parameters. The results of this study suggest that SPIONs and quercetin have considerable effects on neuritogenesis, specifically the neurite arborization. Findings of the present study showed that the combination of iron oxide nanoparticles with a flavonoid can be an appropriate candidate for improving the efficiency of NGF during differentiation.

\section{Data sharing statement}

The data sets used and/or analyzed during the present study are available from the corresponding author upon reasonable request.

\section{Acknowledgments}

We thank the vice chancellor for research and technology of the University of Isfahan. The authors are grateful to the University of Isfahan for providing support to undertake this work. This work was supported by the grant from the University of Isfahan.

\section{Author contributions}

All authors contributed toward data analysis, drafting and revising the paper, gave final approval of the version to be published and agree to be accountable for all aspects of the work.

\section{Disclosure}

The authors report no conflicts of interest in this work.

\section{References}

1. Schmidt CE, Leach JB. Neural tissue engineering: strategies for repair and regeneration. Annu Rev Biomed Eng. 2003;5(1):293-347.

2. Kalil K, Dent EW. Branch management: mechanisms of axon branching in the developing vertebrate CNS. Nat Rev Neurosci. 2014;15(1):7-18.

3. Stoll G, Müller HW. Nerve injury, axonal degeneration and neural regeneration: basic insights. Brain Pathol. 1999;9(2):313-325.

4. Greene LA, Tischler AS. Establishment of a noradrenergic clonal line of rat adrenal pheochromocytoma cells which respond to nerve growth factor. Proc Natl Acad Sci Unit States Am. 1976;73(7):2424-2428.

5. Tsuji $\mathrm{M}$, Inanami $\mathrm{O}$, Kuwabara $\mathrm{M}$. Induction of neurite outgrowth in PC12 cells by alpha-phenyl- $N$-tert-butylnitron through activation of protein kinase $\mathrm{C}$ and the Ras-extracellular signal-regulated kinase pathway. J Biol Chem. 2001;276(35):32779-32785.
6. Gupta AK, Gupta M. Synthesis and surface engineering of iron oxide nanoparticles for biomedical applications. Biomaterials. 2005;26(18): 3995-4021.

7. Ito A, Shinkai M, Honda H, Kobayashi T. Medical application of functionalized magnetic nanoparticles. J Biosci Bioeng. 2005;100(1):1-11.

8. Litovsky S, Madjid M, Zarrabi A, Casscells SW, Willerson JT, Naghavi M. Superparamagnetic iron oxide-based method for quantifying recruitment of monocytes to mouse atherosclerotic lesions in vivo: enhancement by tissue necrosis factor-alpha, interleukin-1beta, and interferon-gamma. Circulation. 2003;107(11):1545-1549.

9. Hong J-H, Noh K-M, Yoo Y-E, et al. Iron promotes the survival and neurite extension of serum-starved PC12 cells in the presence of NGF by enhancing cell attachment. Mol Cells. 2003;15(1):10-19.

10. Enteshari Najafabadi R, Kazemipour N, Esmaeili A, Beheshti S, Nazifi S. Using superparamagnetic iron oxide nanoparticles to enhance bioavailability of quercetin in the intact rat brain. BMC Pharmacol Toxicol. 2018;19(1):59.

11. Kotake-Nara E, Takizawa S, Quan J, Wang H, Saida K. Cobalt chloride induces neurite outgrowth in rat pheochromocytoma PC-12 cells through regulation of endothelin-2/vasoactive intestinal contractor. J Neurosci Res. 2005;81(4):563-571.

12. Lein P, Gallagher PJ, Amodeo J, Howie H, Roth JA. Manganese induces neurite outgrowth in PC12 cells via upregulation of alpha(v) integrins. Brain Res. 2000;885(2):220-230.

13. Roth JA, Horbinski C, Higgins D, Lein P, Garrick MD. Mechanisms of manganese-induced rat pheochromocytoma (PC12) cell death and cell differentiation. Neurotoxicology. 2002;23(2):147-157.

14. Häfeli UO, Riffle JS, Harris-Shekhawat L, et al. Cell uptake and in vitro toxicity of magnetic nanoparticles suitable for drug delivery. Mol Pharm. 2009;6(5):1417-1428.

15. Yarjanli Z, Ghaedi K, Esmaeili A, Rahgozar S, Zarrabi A. Iron oxide nanoparticles may damage to the neural tissue through iron accumulation, oxidative stress, and protein aggregation. BMC Neurosci. 2017; 18(1):51.

16. Singh N, Jenkins GJS, Asadi R, Doak SH. Potential toxicity of superparamagnetic iron oxide nanoparticles (SPION). Nano Reviews. 2010;1(1):5358.

17. Oberdörster G, Stone V, Donaldson K. Toxicology of nanoparticles: a historical perspective. Nanotoxicology. 2007;1(1):2-25.

18. Stroh A, Zimmer C, Gutzeit C, et al. Iron oxide particles for molecular magnetic resonance imaging cause transient oxidative stress in rat macrophages. Free Radic Biol Med. 2004;36(8):976-984.

19. Ishige K, Schubert D, Sagara Y. Flavonoids protect neuronal cells from oxidative stress by three distinct mechanisms. Free Radic Biol Med. 2001;30(4):433-446.

20. Choi D-Y, Lee Y-J, Hong JT, Lee H-J. Antioxidant properties of natural polyphenols and their therapeutic potentials for Alzheimer's disease. Brain Res Bull. 2012;87(2-3):144-153.

21. Lau FC, Shukitt-Hale B, Joseph JA. The beneficial effects of fruit polyphenols on brain aging. Neurobiol Aging. 2005;26(1):128-132.

22. Cao G, Sofic E, Prior RL. Antioxidant and prooxidant behavior of flavonoids: structure-activity relationships. Free Radic Biol Med. 1997;22(5):749-760.

23. Kumari A, Yadav SK, Pakade YB, Singh B, Yadav SC. Development of biodegradable nanoparticles for delivery of quercetin. Colloids Surf B. 2010;80(2):184-192.

24. Wu T-H, Yen F-L, Lin L-T, Tsai T-R, Lin C-C, Cham T-M. Preparation, physicochemical characterization, and antioxidant effects of quercetin nanoparticles. Int J Pharm. 2008;346(1-2):160-168.

25. Murakami A, Ashida H, Terao J. Multitargeted cancer prevention by quercetin. Cancer Lett. 2008;269(2):315-325.

26. Sagara Y, Vanhnasy J, Maher P. Induction of PC12 cell differentiation by flavonoids is dependent upon extracellular signal-regulated kinase activation. J Neurochem. 2004;90(5):1144-1155.

27. Chan GKL, Hu WWH, Zheng ZX, et al. Quercetin potentiates the NGFinduced effects in cultured PC12 cells: identification by HerboChips showing a binding with NGF. Evid Based Complementary Altern Med. 2018;2018(1):1-9. 
28. Mosmann T. Rapid colorimetric assay for cellular growth and survival: application to proliferation and cytotoxicity assays. J Immunol Methods. 1983;65(1-2):55-63.

29. Kim JA, Lee N, Kim BH, et al. Enhancement of neurite outgrowth in PC12 cells by iron oxide nanoparticles. Biomaterials. 2011;32(11): 2871-2877.

30. Alexiou C, Jurgons R, Seliger C, Brunke O, Iro H, Odenbach S. Delivery of superparamagnetic nanoparticles for local chemotherapy after intraarterial infusion and magnetic drug targeting. Anticancer Res. 2007; 27(4A):2019-2022.

31. Smith SW. "Reticular" and "Areticular" nissl bodies in sympathetic neurons of a lizard. J Cell Biol. 1959;6(1):77-84.

32. Nel A, Xia T, Mädler L, Li N. Toxic potential of materials at the nanolevel. Science. 2006;311(5761):622-627.

33. Pisanic TR, Blackwell JD, Shubayev VI, Fiñones RR, Jin S. Nanotoxicity of iron oxide nanoparticle internalization in growing neurons. Biomaterials. 2007;28(16):2572-2581.

34. Keegan K, Halegoua S. Signal transduction pathways in neuronal differentiation. Curr Opin Neurobiol. 1993;3(1):14-19.

35. Yoo Y-E, Hong J-H, Hur KC, Oh E-S, Chung J-M. Iron enhances NGFinduced neurite outgrowth in PC12 cells. Mol Cells. 2004;17(2):340-346.

36. Pang L, Sawada T, Decker SJ, Saltiel AR. Inhibition of MAP kinase kinase blocks the differentiation of PC-12 cells induced by nerve growth factor. J Biol Chem. 1995;270(23):13585-13588.

37. Berry CC, Charles S, Wells S, Dalby MJ, Curtis ASG. The influence of transferrin stabilised magnetic nanoparticles on human dermal fibroblasts in culture. Int J Pharm. 2004;269(1):211-225.

38. Polak P, Shefi O. Nanometric agents in the service of neuroscience: manipulation of neuronal growth and activity using nanoparticles. Nanomedicine. 2015;11(6):1467-1479.
39. Tangsaengvit N, Kitphati W, Tadtong S, Bunyapraphatsara N Nukoolkarn V. Neurite outgrowth and neuroprotective effects of quercetin from Caesalpinia mimosoides lamk on cultured P19-derived neurons. Evidence Based Complementary Altern Med. 2013;2013(2):1-7.

40. Maher P, Akaishi T, Abe K. Flavonoid fisetin promotes ERK-dependent long-term potentiation and enhances memory. Proc Natl Acad Sci. 2006; 103(44):16568-16573.

41. Prouillet C, Mazière J-C, Mazière C, Wattel A, Brazier M, Kamel S. Stimulatory effect of naturally occurring flavonols quercetin and kaempferol on alkaline phosphatase activity in MG-63 human osteoblasts through ERK and estrogen receptor pathway. Biochem Pharmacol. 2004;67(7):1307-1313.

42. $\mathrm{Pu} \mathrm{F}$, Mishima K, Irie K, et al. Neuroprotective effects of quercetin and rutin on spatial memory impairment in an 8-arm radial maze task and neuronal death induced by repeated cerebral ischemia in rats. J Pharmacol Sci. 2007;104(4):329-334.

43. Oravecz K, Kalka D, Jeney F, Cantz M, Zs-Nagy I. Hydroxyl free radicals induce cell differentiation in SK-N-MC neuroblastoma cells. Tissue and Cell. 2002;34(1):33-38.

44. Dent EW, Gupton SL, Gertler FB. The growth cone cytoskeleton in axon outgrowth and guidance. Cold Spring Harb Perspect Biol. 2011;3(3):a001800.

45. Bear JE, Gertler FB. Ena/VASP: towards resolving a pointed controversy at the barbed end. J Cell Sci. 2009;122(12):1947-1953.

46. Korobova F, Svitkina T. Arp2/3 complex is important for filopodia formation, growth cone motility, and neuritogenesis in neuronal cells. Mol Biol Cell. 2008;19(4):1561-1574.
International Journal of Nanomedicine

\section{Publish your work in this journal}

The International Journal of Nanomedicine is an international, peerreviewed journal focusing on the application of nanotechnology in diagnostics, therapeutics, and drug delivery systems throughout the biomedical field. This journal is indexed on PubMed Central,

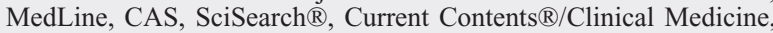

\section{Dovepress}

Journal Citation Reports/Science Edition, EMBase, Scopus and the Elsevier Bibliographic databases. The manuscript management system is completely online and includes a very quick and fair peer-review system, which is all easy to use. Visit http://www.dovepress.com/ testimonials.php to read real quotes from published authors. 